\title{
NOTE
}

\section{Samplers for enclosed stratified water columns*}

\author{
U. H. Brockmann ${ }^{1}$ and G. Hentzschel ${ }^{2}$ \\ ' Institut für Organische Chemie und Biochemie, SFB 94, Universität Hamburg, Martin-Luther-King-Platz 6, D-2000 Hamburg 13, \\ Federal Republic of Germany \\ ${ }^{2}$ Institut für Allgemeine Botanik, Abteilung für Mikrobiologie, Ohnhorststraße 18, D-2000 Hamburg 52, Federal Republic of Germany
}

\begin{abstract}
The 2 samplers described were developed especially for use in small enclosures. Made from physiologically inert materials, both samplers can be operated by 1 line each. Especially the ball-sampler - a cylinder closed by 2 balls introduces only little turbulence into the enclosed water column, so that in a stratified water column frequent sampling is possible for some weeks without destruction of the pycnocline.
\end{abstract}

Enclosures have come into more frequent use for investigating planktonic ecosystems (Kinne, 1976; Zeitzschel, 1978; Davies and Gamble, 1979; Grice and Reeve, 1982). Different designs have been developed according to the aims of experiment.

For analysing the interactions between chemical components and bacterio-, phyto- and herbivorous zooplankton, relatively simple and small enclosures made of translucent plastic foils are used (Brockmann et al., 1974, 1977a, b; Kuiper, 1977). Smaller enclosures with diameters in the range of $1 \mathrm{~m}$ have the advantage that sampling of a few liters at a definite depth will be representative for this depth. This is not the case in larger enclosures of about $10 \mathrm{~m}$ diameter, in which the advantages of using an enclosure are partly lost by horizontal plankton gradients which can develop at some times (Takahashi et al., 1975; Grice et al., 1977).

Sampling in smaller enclosures is more difficult than in large ones because plastic foils can be damaged. If stratification in very deep enclosures is to be included among the ecosystem variables, care must be taken not to destroy the stratification while sampling. For these reasons sampling with flap-samplers such as Niskin samplers is not recommended within smaller enclosures.

Tubes. Taking into account the conditions mentioned above, the best way of sampling would be by drawing samples through tubes using pumps or vacuum. In this way sampling would be representative with respect to phytoplankton but not to larger zooplankton.

\footnotetext{
- This work was supported by the 'Deutsche Forschungsgemeinschaft' in 'Sonderforschungsbereich 94' - Marine Research - Hamburg

This sampling procedure has been used in enclosures with monocultures of diatoms (Brockmann et al., 1977a; Eberlein et al., 1983). Using silicone tubes, which can be sterilized from time to time, bacteria can also be sampled representatively.

Ball sampler. For frequent sampling in stratified enclosures containing natural plankton populations we developed a 31 sampler with a hydrodynamically smooth profile in order to reduce turbulence when the sampler is moved through the water column. The sampler is constructed mainly from physiologically inert plastics like delrin, acryl glass, silicone and nylon. All metal parts are encapsulated in plastic. A $30 \mathrm{~cm}$ long cylinder with a diameter of $15 \mathrm{~cm}$, fastened to a central sleeve by small rods, can be closed by 2 balls (Fig. 1). The balls are connected by a central rod, along which the sleeve, which fits around the rod, can be moved.

To open the sampler the upper ball is lifted and locked by 2 small balls which are pressed by rubber springs into a groove around the central rod. The pressure of the springs can be regulated by screws in the outer part of the top ball (Fig. 2). To keep the cylinder open at both ends, nylon threads are used for lifting the cylinder from the lower ball. The sampler is attached to a non-elastic polypropylene rope and can be closed by a short tug on this rope, by which the upper ball will be freed. The cylinder is now pressed by the weight of the upper massive delrin ball (density $=1.4$ ) against the lower ball. Gaskets of silicone rubber seal the sampler completely so that no water is lost. For constructions of larger-volume samplers the weight of the upper ball must be increased correspondingly to the volume to avoid leakage. The structure of the closed sampler is similar to that of a modified VanDorn sampler (Finucane and May, 1961), but this causes much more turbulence by closing than our system.

By applying pressure on both balls the sampler may be inverted for emptying. We used a support to keep the sampler in an inclined position. By opening the inlet and the stopcock the sample can be transferred within a few min. 


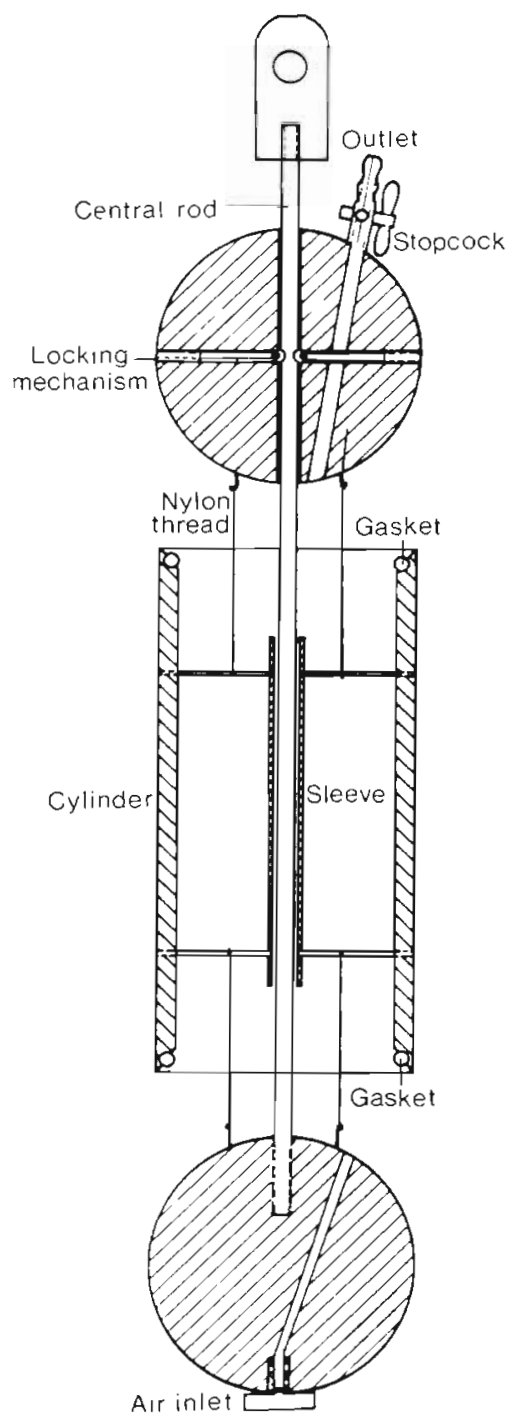

Fig. 1. Ball sampler. The $3 \mathrm{dm}^{3}$-sampler is constructed from physiological inert plastics for use in small enclosures with stratified water columns. The cylinder, inner diameter of $13 \mathrm{~cm}$ and length of $30 \mathrm{~cm}$, is closed by 2 delrin balls $(1.8 \mathrm{~kg}$ each)

We used this sampler with a rope running through a block fastened about $2 \mathrm{~m}$ above water level. For example, within $15 \mathrm{~d}$ we took more than 90 samples from each of the following depths: $0,3,10,20$ and $35 \mathrm{~m}$, out of a $40 \mathrm{~m}$ deep enclosure with a diameter of $1 \mathrm{~m}$. This enclosure was filled with stratified water of $S=30.0$ in the upper and $S=34.2$ in the lower layer. The boundary was at a depth of $14 \mathrm{~m}$. Water temperatures varied from 0.5 to $5.5^{\circ} \mathrm{C}$, and the resultant density differences were between $\zeta_{\mathrm{t}}=2.2$ at the beginning to $\zeta_{\mathrm{t}}=1$ at the end of experiment. This stratification became weaker, but was not destroyed (although the pycnocline was penetrated more than 360 times with the opened and closed sampler), as noted also from frequent nutrient

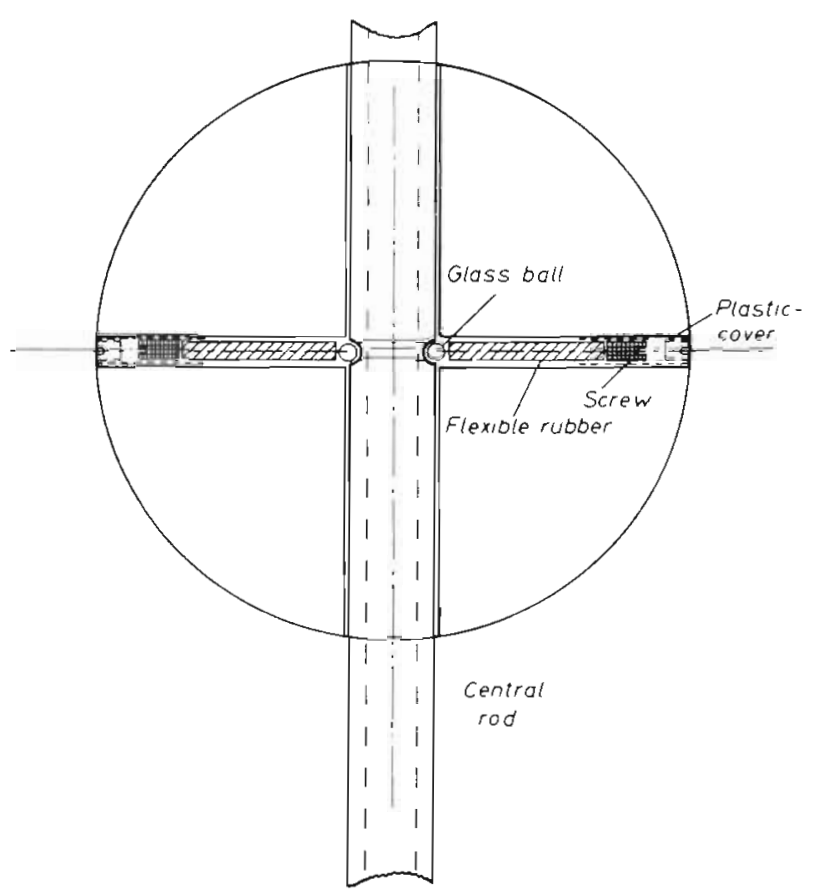

Fig. 2. Detail of ball sampler: Locking mechanism for keeping the sampler in an open position. Two small balls are pressed

by flexible rubber into a groove around the central rod

measurements (Brockmann et al., 1982; Kattner et al., 1983, enclosure CC). Only about $15 \%$ of nitrate concentration in the nutrient-rich lower layer were lost from the $20 \mathrm{~m}$ level to the nutrient-poor upper layer by diffusion and frequent sampling. In other enclosures nutrient stratification could also be observed and was maintained at density differences below $\zeta_{t}=0.5$ for several weeks.

Microbiological sampler. Within the same enclosures a less smoothly profiled microbiological sampler was used twice a day in the upper depths, down to $10 \mathrm{~m}$. This sampler was constructed from a $250 \mathrm{ml}$ duran glass bottle which is closed with a silicone stopper through which 2 glass tubes are inserted, 1 with a tapered outlet (Fig. 3). To the glass tubes silicone rubber tubes are fixed which can be closed by a clamp so that the bottle can be autoclaved. Attached to the bottle is a plastic encapsulated weight. The bottle is suspended from a plastic ring, held in place by a plastic screw. The ring is fastened to a polyethylene line, running on a small winch.

The clamp on the silicone tube is also fastened to the line within a loop which is stabilized by a small silicone rubber tube and two knots. This sampler can also be closed by a small tug at the line causing the loop to collapse and removing the clamp. Now the sampler will be filled through the tube with the larger diameter, while air escapes through the tapered tube.

A similar construction was used keeping the bottle 


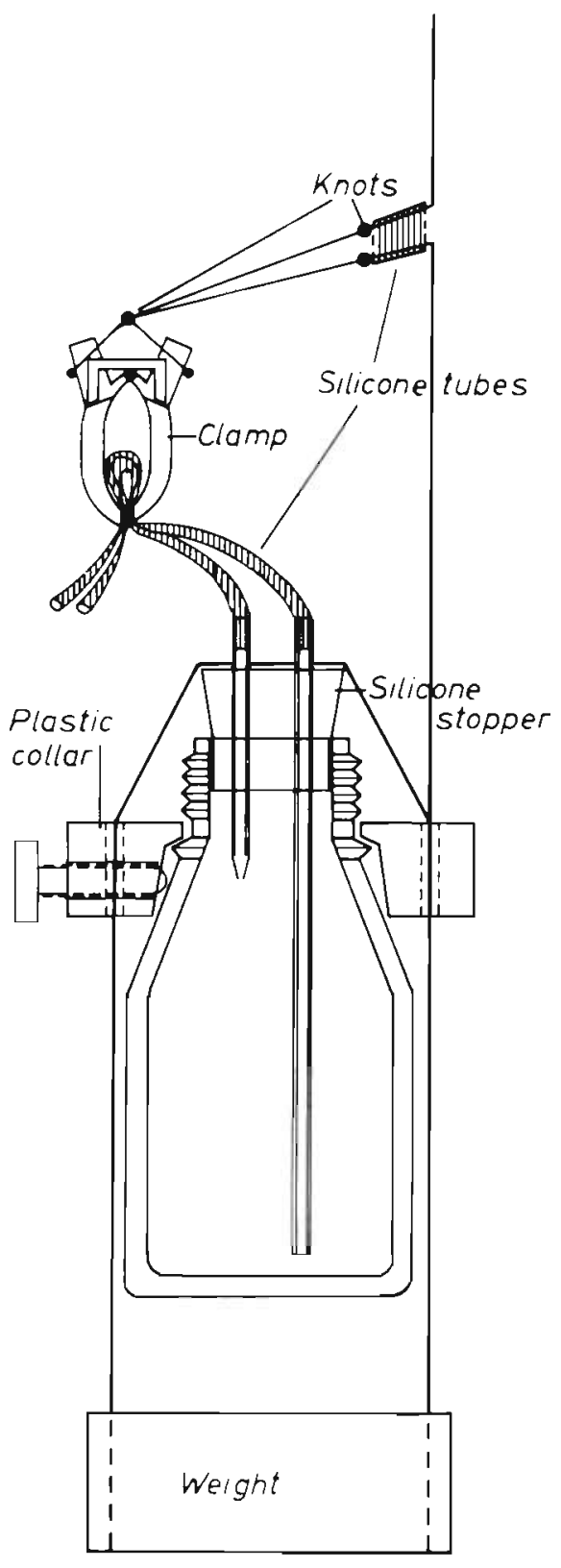

Fig. 3. Microbiological sampler. A $250 \mathrm{ml}$ duran glass bottle, closed by a fixed silicone stopper, can be filled by a glass tube inserted to the stopper while the air escapes through a tapered tube with a smaller diameter

above the surface, and filling it by a long, weighed, sterilized silicone rubber tube (fixed to the larger glass tube in the stopper) and lowered to the desired depth. The sample was drawn in by a vacuum. By this procedure stratification within the enclosure is disturbed less than by generating air bubbles. In the first procedure, however, there is less risk of contamination. A comparison of the various procedures gave no significant differences in results.

Acknowledgements. We are grateful to $\mathrm{H}$. Fichtner and $\mathrm{H}$ Rost for constructing the samplers. We thank R. Lucht for typing, G. Kramm for drawing the figures and B. Kronberg for reading the manuscript.

\section{LITERATURE CITED}

Brockmann, U. H., Eberlein, K., Junge, H. D., Trageser, H., Trahms, K. J. (1974). Einfache Folientanks zur Planktonuntersuchung in situ. Mar. Biol. 24: 163-166

Brockmann, U. H., Eberlein, K., Hentzschel, G., Schöne, H. K., Siebers, D., Wandschneider, K., Weber, A. (1977a). Parallel plastic tank experiments with cultures of marine diatoms. Helgoländer wiss. Meeresunters. 30: 201-216

Brockmann, U. H., Eberlein, K., Hosumbek, P., Trageser, H., Maier-Reimer, E., Schöne, H. K., Junge, H. D. (1977b). The development of a natural plankton population in an outdoor tank with nutrient-poor sea water. I. Phytoplankton succession. Mar. Biol. 43: 1-17

Brockmann, U. H., Kattner, G., Dahl, E. (1982). Plankton spring development in a south Norwegian fjord. In: Grice, G. D., Reeve, M. R. (ed.) Marine mesocosms. Springer, New York, p. 195-204

Davies, J. M., Gamble, J. C. (1979). Experiments with large enclosed ecosystems. Phil. Trans. R. Soc. Lond. B 286: $523-544$

Eberlein, K., Brockmann, U. H., Hammer, K. D., Kattner, G., Laake, M. (1983). Total dissolved carbohydrates in an enclosure experiment with unialgal Skeletonema costatum culture. Mar. Ecol. Prog. Ser. 14: 45-58

Finucane, J H., May, B. Z. (1961). Modified VanDorn water sampler. Limnol. Oceanogr. 6: 85-87

Grice, G. D., Reeve, M. R., Koeller, P., Menzel, D. W. (1977). The use of large volume, transparent, enclosed sea-surface water columns in the study of stress on plankton ecosystems. Helgoländer wiss. Meeresunters. 30: 118-133

Grice, G. D., Reeve, M. R. (1982). Introduction and description of experimental ecosystems. In: Grice, G. D., Reeve, M. R. (ed.) Marine mesocosms. Springer, New York, p. 12-19

Kattner, G., Hammer, K. D., Eberlein, K., Brockmann, U. H. Jahnke, J., Krause, M. (1983). Nutrient and plankton development in Rosfjorden and enclosed ecosystems captured from the changing water bodies during POSER. Mar. Ecol. Prog. Ser. 14: 29-43

Kinne, O. (1976). Cultivation of marine organisms: waterquality management and technology. In: Kinne, O. (ed.) Marine ecology, Vol. III, Cultivation, Part 1. Wiley, Chichester, p. 19-300

Kuiper, J. (1977). Development of North Sea coastal plankton communities in separate plastic bags under identical conditions. Mar. Biol. 44: 97-107

Takahashi, M., Thomas, W. H., Seibert, D. L. R., Beers, J., Koeller, P., Parsons, T. R. (1975). The replication of biological events in enclosed water columns. Arch. Hydrobiol. 1: $5-23$

Zeitzschel, B. (1978). Controlled environment experiments in pollution studies. Ocean Mgmt 4: 319-344

Accepted for printing on June 10, 1983 